\title{
PENERAPAN TEKNOLOGI BIODRYING DALAM PENGOLAHAN SAMPAH HIGH WATER CONTENT MENUJU ZERO LEACHATE
}

\author{
Purwono*, Mochatar Hadiwidodo, Arya Rezagama \\ Departemen Teknik Lingkungan \\ Fakultas Teknik, Universitas Diponegoro \\ Jl. Prof. H. Sudarto, SH., Tembalang, Semarang, Jawa Tengah \\ Email: * pur_121@yahoo.com
}

\begin{abstract}
ABSTRAK
Pada tahun 2025, Indonesia diperkirakan akan menghasilkan sampah sebanyak 130.000 ton/hari. Sebagian besar sampah masih menjadi sumber penyebab polusi dan berpotensi mengurangi sumber air bersih. Jumlah limbah makanan relatif tinggi (> 60\%) dan lainnya merupakan sampah yang dapat didaur ulang, seperti plastik, kertas, gelas, dan logam. Tetapi limbah makanan tidak dapat dilakukan daur ulang maupun sortir karena mengandung kadar air sangat tinggi hingga $74,5 \%$. Limbah ini sangat berpotensi menghasilkan pencemar berupa lindi (leachate). Biodrying pengolahan sampah diharapkan mampu mengurangi volume lindi. Penambahan aerasi pada proses biodrying hanya menghasilkan lindi sebesar 1.279,5 ml dengan debit 3 liter/menit sedangkan tanpa aerasi menghasilakn lindi lebih banyak sebesar $1.607,5 \mathrm{ml}$. Suhu kompos tertinggi terjadi pada hari kedua mencapai $34{ }^{\circ} \mathrm{C}$. Setelah hari keenam semua reaktor menunjukkan grafik kenaikan dan penurunan suhu sampah yang realtif seragam. Nilai pH berkisaran antara 6,09-8,88 dan nilai COD akhir pada reaktor kontrol tanpa aerasi sebesar 14.116,67 mg/l sedangkan COD paling rendah sebesar $13.360 \mathrm{mg} / \mathrm{l}$ yang dihasilkan dari reaktor dengan debit $2 \mathrm{l} / \mathrm{m}$. Tujuan mencapai zero lechate belum tercapai tetapi proses biodrying mampu mengurangi volume lindi yang dihasilkan.
\end{abstract}

Kata kunci: Biodrying, zero lechate, COD, limbah sayuran

\section{PENDAHULUAN}

Fakta menunjukkan bahwa Indonesia merupakan negara dengan penduduk terbanyak keempat di dunia dengan total penduduk sekitar 237 juta. Diperkirakan jumlah penduduk akan bertambah menjadi 270 juta pada tahun 2025. Pertambahan jumlah penduduk tersebut diperkirakan akan menghasilkan sampah sebanyak 130.000 ton/hari (Harian semarang, 2016). Di satu sisi, ini merupakan potensi besar sebagai sumber daya seperti bahan yang dapat di daur ulang dan sumber energi. Tetapi saat ini sebagian besar sampah masih menjadi sumber penyebab polusi dan berpotensi mengurangi sumber air bersih. Limbah merupakan zat atau bahan buangan yang dihasilkan dari proses kegiatan manusia (Suharto, 2011). Jumlah limbah makanan relatif tinggi (> 60\%) dan lainnya merupakan sampah yang dapat didaur ulang, seperti plastik, kertas, gelas, dan logam. Pengelolaan selain limbah makanan dapat dilakukan dengan cara penyortiran mekanik atau manual. Tetapi limbah makanan tidak dapat dilakukan daur ulang maupun sortir karena mengandung kadar air sangat tinggi hingga $74,5 \%$ Limbah ini sangat berpotensi menghasilkan pencemar berupa lindi (leachate) (He dkk, 2005).

Teknologi pengolahan limbah padat meliputi pembuatan kompos, metode termal, dan penimbunan. Metode termal sangat efisien untuk mengurangi volume dalam waktu singkat dan recoveri energi sebagai energi terbarukan. Biodrying (Biological drying) merupakan salah satu alternatif biokonversi mekanikal-biologikal untuk mengolah sampah. Proses ini dapat diterapkan dalam suatu reaktor. Biodrying mengintegrasikan proses mekanik (pencacahan sampah dan sirkulasi udara) dan biokonversi (komposting dan pengolahan anaerobic). Dalam prakteknya, reaktor biodrying memproses sampah dengan kadar air tinggi yang sudah dicacah dan menghasilkan output sampah kering (biodried) yang akan mengalami proses mekanis lebih lanjut. Panas yang dihasilkan dari proses dekomposisi aerobik senyawa organik dikombinasikan dengan udara berlebih 
berfungsi mengeringkan sampah (Velis dkk. 2009).

Proses biodrying fokus pada teknologi aerobik yaitu menghilangkan air terutama sebagai uap akibat adanya suhu pengomposan dan ventilasi yang memadai. Adani, dkk. (2002) dan Sugni, dkk. (2005) menunjukkan bahwa pengaturan aerasi dan suhu yang tepat dapat meningkatkan efisiensi pengeringan 66,7 \% dari kadar air awal. Ketika rasio kadar air terhadap bahan organik biodegradable terlalu tinggi, maka panas yang dihasilkan dari proses biodegradasi tidak cukup untuk menguapkan air. Di sisi lain, proses degradasi limbah (kadar air tinggi) akan menghasilkan lindi yang semakin banyak. Lindi hanya akan timbul ketika dinding sel atau membran limbah hancur. Proses timbulnya lindi terjadi pada tahap hidrolisis karena penguraian bahan organik sangat sedit. Akibatnya volume lindi semakin banyak dan kandungan bahan organiknya tinggi. Pada proses ini penguraian bahan organik menjadi $\mathrm{CO}_{2}$ sangat sedikit. Jumlah lindi dapat dikendalikan dengan mengatur aerasi agar terjadi peningkatan penguraian parsial dan hidrolisis senyawa organik makromolekul (Nguyen dkk, 2007).

Bezama dkk, (2007) menunjukkan bahwa pada tahap hidrolisis dihasilkan lindi sebanyak $42 \%$. Adanya proses biodriying menunjukkan bahwa lindi tidak dihasilkan (Zero leachate). Target penelitian ini bukan hanya fokus pada jumlah lindi yang dihasilkan, tetapi mengevaluasi kandungan fisik dan kimia lindi sampah bahan makanan terutama limbah sayuran.

\section{METODOLOGI PENELITIAN}

Limbah padat yang digunakan berasal dari limbah pasar yang didominasi oleh sayuran. Pasar Peterongan, Kota Semarang. Metode yang digunakan pada penelitian ini yaitu menggunakan miniatur 7 buah reaktor cyclic berbahan PVC dengan ukuran seperti pada Gambar 1 yang dilengkapi dengan rangkaian aerator. Pada ujung aerator ditambahkan difuser untuk mengoptimalkan aerasi. Didalam reaktor ini diharapkan terjadi proses biodrying. Kecepatan alir divariasikan $0,2,3,4,5,6$, dan $7 \mathrm{l} /$ menit. Parameter yang dianalisa yaitu volume lindi, Chemical Oxygen Demand (COD) dan $\mathrm{pH}$ lindi serta suhu kompos. Metode pengukuran volume lindi menggunakan gelas ukur. Parameter $\mathrm{pH}$ diukur menggunakan $\mathrm{pH}$ meter merek Walklab seri TI 9000 yang telah terkalibrasi dengan ketelitian 0,01. Suhu kompos diukur menggunakan termometer digital dengan ketelitian $0,1{ }^{\circ} \mathrm{C}$. Parameter COD diukur menggunakan metode closed refluks. Semua reagent yang digunakan memiliki kualitas pro analisis (p.a) dengan merek dagang Merck, Germany. Gambar rangkaian biodrying ditunjukkan pada Gambar 1 berikut:

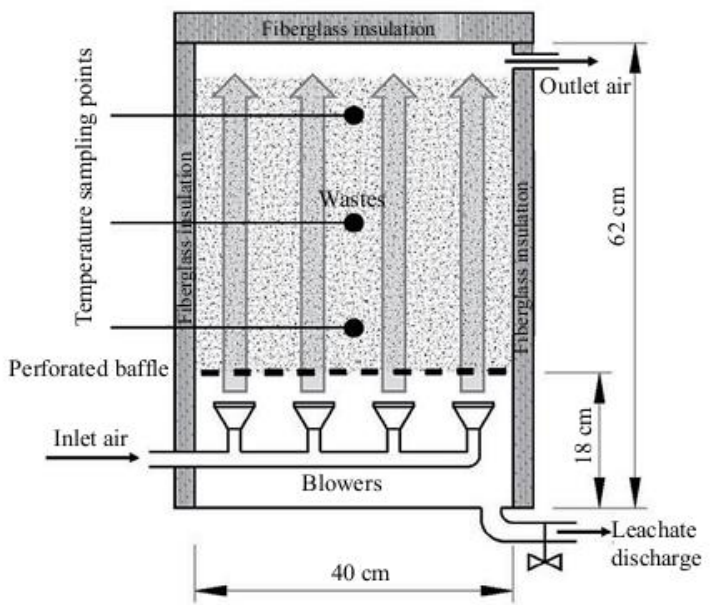

Gambar 1. Reaktor biodrying terbuat dari bahan PVC

\section{HASIL DAN PEMBAHASAN}

Pengaruh Kecepatan Alir Udara Terhadap Volume Lindi

Volume lindi yang dihasilkan berbedabeda akibat perubahan debit aerasi. Volume lindi yang dihasilkan ditunjukkan pada grafik berikut:

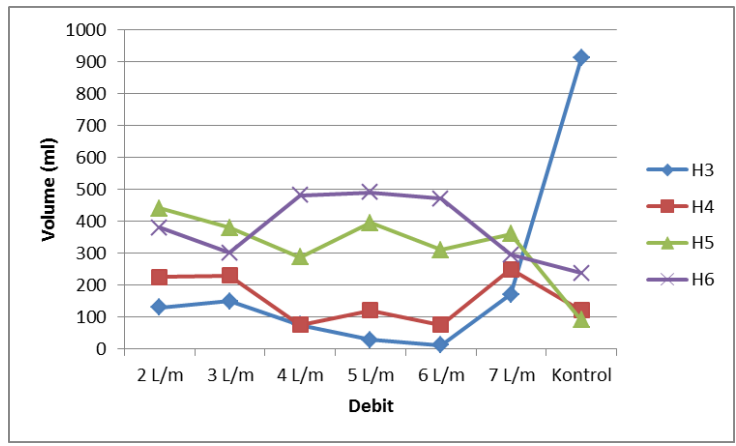

(a)

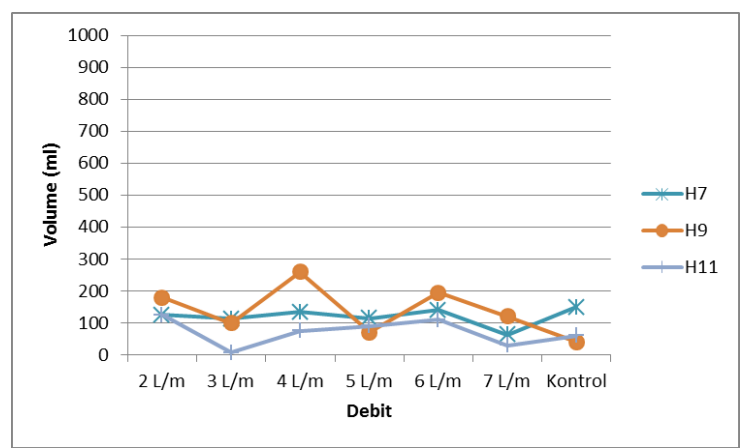

(b)

Gambar 2. Grafik volume lindi yang dihasilkan akibat pengaruh variasi debit 
Berdasarkan hasil pengamatan dan perhitungan volume dapat disimpulkan bahwa pemberian aerasi memberikan efek positif dan signifikan untuk mengurangi jumlah produksi lindi yang terbentuk sehingga reaktor yang diberi aerasi memiliki jumlah total produksi lindi lebih sedikit dari reaktor kontrol. Pemberian aerasi pada reaktor pengolahan sampah secara biodrying tidak memberikan efek yang signifikan terhadap pengurangan produksi lindi jika dilihat dari jumlah produksi lindi yang dihasilkan dalam satuan hari. Namun hal yang berlawanan terlihat pada hasil akhir (total) produksi lindi.

Hal ini terjadi karena metode biodrying merupakan teknik pengeringan yang mengandalkan aktivitas biologis mikroorganisme baik bakteri maupun jamur, untuk mengurangi kadar air dari biomaterial sampah basah (Sadaka dkk, 2010). Pengeringan dan pengurangan kadar air yang terjadi dibantu oleh adanya pemberian aerasi. Aerasi menyuplai oksigen pada mikroorganisme untuk mendukung kondisi pertumbuhannya dan membawa uap yang terevaporasi ke luar reaktor (Ham dkk, 2013). Energy termal dilepaskan selama dekomposisi aerobik materi organik yang dikombinasikan dengan udara bebas untuk mengeringkan sampah (Velis dkk, 2008). Dengan demikian proses pengeringan sampah terjadi akibat panas hasil aktivitas mikroorganisme sehingga menguapkan kadar air sampah serta melalui penguapan oleh pemberian aerasi. Pengurangan jumlah produksi lindi tidak terlihat pada satuan hari karena proses degradasi sampah yang memerlukan waktu yang berbeda pada setiap debit aerasi.

\section{Sampah \\ Pengaruh Debit Aerasi Terhadap Suhu}

Berdasarkan penelitian yang telah dilakukan dapat dilihat bahwa suhu sampah dari reaktor yang diberi aerasi dan yang tidak diberi aerasi semuanya mengalami kenaikan dan penurunan suhu yang fluktuatif. Pada hari kedua reaktor kontrol memiliki suhu paling tinggi yaitu $34,7^{\circ} \mathrm{C}$ diikuti oleh reaktor $3 \mathrm{~L} / \mathrm{m}$ dengan suhu $34^{\circ} \mathrm{C}$. Sedangkan reaktor $7 \mathrm{~L} / \mathrm{m}$ memiliki suhu terendah pada hari kedua dengan suhu $25,6^{\circ} \mathrm{C}$ diikuti oleh reaktor $6 \mathrm{~L} / \mathrm{m}$ dengan suhu $27,1^{\circ} \mathrm{C}$. Suhu sampah terendah selama proses pengolahan sampah terjadi pada reaktor dengan debit aerasi $3 \mathrm{~L} / \mathrm{m}$ di hari keenam dan kesembilan yaitu $25,3^{\circ} \mathrm{C}$. Dan kenaikan suhu tertinggi terjadi pada reaktor kontrol di hari kedua yaitu $34,7^{\circ} \mathrm{C}$. Bentuk grafik fluktuasi suhu sampah dari semua reaktor umumnya sama yaitu mencapai puncak suhu tertinggi pada hari kedua dan ketiga selanjutnya mengalami kenaikan dan penurunan fluktuatif hingga hari kelima.
Memasuki hari keenam semua reaktor menunjukkan grafik kenaikan dan penurunan suhu sampah yang realtif seragam.

Tingginya suhu sampah pada hari kedua dan ketiga dapat disebabkan oleh adanya aktivitas metabolisme mikroorganisme yang tinggi. Temperature adalah parameter terjadinya proses eksotermik dan metabolisme respirasi mikroorganisme. Metabolisme mikroorganisme erat kaitannya dengan fraksi organic, sehingga apabila temperature semakin tinggi maka proses metabolisme mikroorganisme juga tinggi (Fadlilah dan Yudihanto, 2013). Pada hari keenam setelah dilakukan pembalikkan, suhu sampah pada seluruh reaktor relative lebih stabil dan memiliki fluktuasi yang seragam. Pembalikkan dilakukan untuk lebih menghomogenkan distribusi nutrisi dan mikroorganisme serta untuk mengatur aktivitas aerobik (Tchobanoglous dkk, 1993). Kestabilan kenaikan dan penurunan sampah setelah dilakukan pembalikan dapat diakibatkan telah seragamnya penyebaran nutrisi dan mikroorganisme sehingga aktivitas aerobik yang terjadi pun lebih stabil.

\section{Lindi \\ Pengaruh Debit Aerasi Terhadap pH \\ Pengukuran $\mathrm{pH}$ lindi dilakukan mulai pada} hari ketiga karena lindi mulai dihasilkan semua reaktor pada hari tersebut. Berdasarkan penelitia ini dapat dilihat bahwa reaktor kontrol memiliki $\mathrm{pH}$ awal lindi yang paling rendah yaitu 6,09 sedangkan reaktor $6 \mathrm{~L} / \mathrm{m}$ memiliki $\mathrm{pH}$ awal paling tinggi sebesar 8,88. Dan pada hari terakhir proses pengolahan sampah reaktor 6 $\mathrm{L} / \mathrm{m}$ memiliki $\mathrm{pH}$ akhir paling rendah sebesar 8,77 sedangkan reaktor $3 \mathrm{~L} / \mathrm{m}$ memiliki $\mathrm{pH}$ akhir paling tinggi sebesar 9,73. Grafik nilai $\mathrm{pH}$ ditunjukkan pada Gambar 3 berikut:

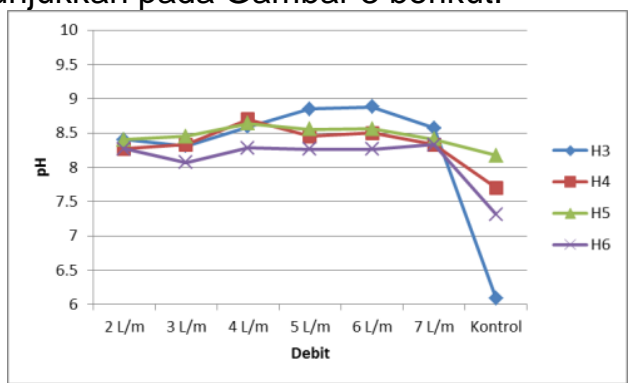

(a)

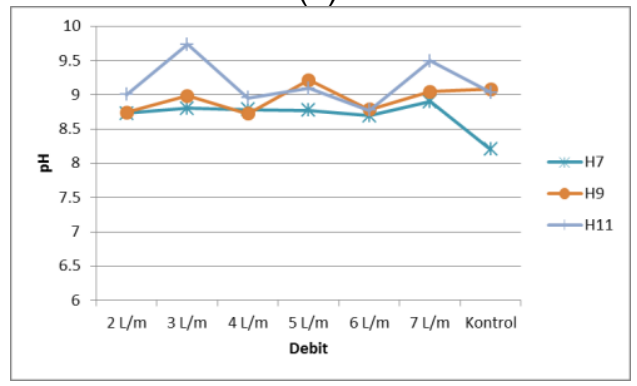

(b) 
Gambar 3. Grafik Pengaruh Debit Aerasi terhadap pH Lindi H3-H6 (a). Pengaruh Debit Aerasi terhadap pH Lindi H7-H11 (b)

Berdasarkan Gambar 3 dapat dilihat fluktuasi $\mathrm{pH}$ lindi yang dihasilkan dari masingmasing reaktor yang diberi aerasi dan kontrol. Pada hari ketiga kisaran $\mathrm{pH}$ berada pada angka 6,09-8,88 dengan $\mathrm{pH}$ tertinggi terjadi pada reaktor $6 \mathrm{~L} / \mathrm{m}$ dan $\mathrm{pH}$ terendah terjadi ada reaktor kontrol. Pada hari keempat $\mathrm{pH}$ paling tinggi terjadi pada reaktor $4 \mathrm{~L} / \mathrm{m}$ sebesar 8,7 dan paling rendah pada reaktor kontrol sebesar 7,7. Pada hari kelima $\mathrm{pH}$ paling tinggi terjadi pada reaktor $4 \mathrm{~L} / \mathrm{m}$ sebesar 8,64 dan paling rendah pada reaktor kontrol sebesar 8,17 . Pada hari keenam $\mathrm{pH}$ paling tinggi terjadi pada reaktor $7 \mathrm{~L} / \mathrm{m}$ sebesar 8,33 dan paling rendah pada reaktor kontrol sebesar 7,31. Pada hari ketujuh $\mathrm{pH}$ paling tinggi terjadi pada reaktor $7 \mathrm{~L} / \mathrm{m}$ sebesar 8,9 dan paling rendah pada reaktor kontrol sebesar 8,2. Pada hari kesembilan $\mathrm{pH}$ paling tinggi terjadi pada reaktor $5 \mathrm{~L} / \mathrm{m}$ sebesar 9,21 dan paling rendah pada reaktor $4 \mathrm{~L} / \mathrm{m}$ sebesar 8,72. Dan pada hari kesebelas $\mathrm{pH}$ paling tinggi terjadi pada reaktor $3 \mathrm{~L} / \mathrm{m}$ sebesar 9,73 dan paling rendah pada reaktor $6 \mathrm{~L} / \mathrm{m}$ sebesar 8,77 .

Pada hari ketiga reaktor kontrol memiliki hasil pengukuran $\mathrm{pH}$ paling rendah yaitu 6,09. Rendahnya $\mathrm{pH}$ awal ini diakibatkan karena tingginya konsentrasi asam lemak volatile. $\mathrm{pH}$ lindi semakin bertambah seiring dengan berjalannya waktu karena berkurangnya sebagian konsentrasi asam lemak volatile bebas yang terionisasi (Bhalla et al., 2012). Sedangkan pada reaktor yang diberi aerasi $\mathrm{pH}$ lindi cenderung lebih tinggi dari reaktor kontrol dengan kisaran $\mathrm{pH}$ awal 8,31-8,88. Hal ini karena kehadiran oksigen yang mempercepat proses nitrifikasi. Proses nitrifikasi terjadi melalui dua tahap, yaitu transformasi ammonium menjadi nitrit oleh bakteri pengoksidasi Nitrosomonas, dan oksidasi nitrit menjadi nitrat oleh Nitrobacter. Laju oksidasi nitrit biasanya terjadi lebih cepat sehingga nitrit lebih jarang ditemukan (Walworth, 2013). Berikut reaksi nitrifikasi:

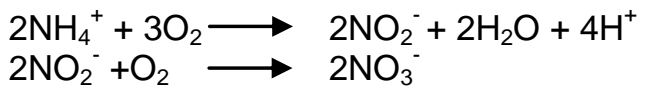

Pada kondisi aerob, ammonium cepat terkonversi menjadi nitrat. Sehingga $\mathrm{pH}$ lindi reaktor aerasi lebih tinggi daripada $\mathrm{pH}$ lindi reaktor kontrol karena sifat nitrat memiliki $\mathrm{pH}$ basa. Selain itu menurut Oncu dkk, (2012) selama proses stabilisasi aerobik, produksi asam lemak tereduksi oleh oksidasi lengkap dari substansi biodegradable menjadi $\mathrm{CO}_{2}$, yang mengakibatkan naiknya $\mathrm{pH}$.

Tabel 1. Pengaruh Debit Aerasi terhadap Konsentrasi COD Lindi

\begin{tabular}{cccccccc}
\hline \multirow{2}{*}{$\begin{array}{c}\text { Hari } \\
\text { ke- }\end{array}$} & $2 \mathrm{~L} / \mathrm{m}$ & $3 \mathrm{~L} / \mathrm{m}$ & $4 \mathrm{~L} / \mathrm{m}$ & $5 \mathrm{~L} / \mathrm{m}$ & $6 \mathrm{~L} / \mathrm{m}$ & $7 \mathrm{~L} / \mathrm{m}$ & Kontrol \\
\hline 3 & 3147 & 6693 & 8827 & 3147 & 3780 & 15960 & 11950 \\
4 & 2913 & 3947 & 2613 & 2613 & 2613 & 2647 & 9783 \\
5 & 3573 & 3840 & 3623 & 3723 & 3473 & 4557 & 9713 \\
6 & 6780 & 7980 & 6813 & 7280 & 7280 & 8147 & 17867 \\
7 & 7047 & 7880 & 5313 & 6613 & 6580 & 8047 & 10627 \\
9 & 8893 & 8293 & 8160 & 9827 & 8827 & 7627 & 8767 \\
11 & 13360 & 37653 & 13360 & 17160 & 15693 & 16960 & 14117 \\
\hline
\end{tabular}

\section{Pengaruh Debit Aerasi Terhadap Konsentrasi COD Lindi}

Pemberian aerasi dengan debit yang berbeda mempengaruhi konsentrasi COD lindi yang dihasilkan dari proses pengolahan sampah organik sayuran kubis secara biodrying. Berikut hasil analisis konsentrasi COD lindi pada masing-masing variasi debit aerasi dapat dilihat pada Tabel 1. Berdasarkan tabel tersebut dapat dilihat bahwa jumlah konsentrasi COD pada hari pertama terbentuknya lindi (hari ketiga penelitian) hingga hari terakhir (hari kesebelas) memiliki konsentrasi yang berfluktuatif berdasarkan debit.

Grafik fluktuasi konsentrasi COD yang dihasilkan berdasarkan debit dapat dilihat pada Gambar 4. Konsentrasi COD paling tinggi pada hari ketiga terjadi pada reaktor 7 L/m sebesar $15960.00 \mathrm{mg} / \mathrm{l}$ dan konsentrasi paling rendah terjadi pada reaktor $2 \mathrm{~L} / \mathrm{m}$ dan 5 L/m sebesar $3146.67 \mathrm{mg} / \mathrm{l}$. Pada hari keempat konsentrasi COD paling tinggi terjadi pada reaktor kontrol juga sebesar $9783.33 \mathrm{mg} / \mathrm{l}$ dan konsentrasi paling rendah pada reaktor $4 \mathrm{~L} / \mathrm{m}$, $5 \mathrm{~L} / \mathrm{m}$ dan $6 \mathrm{~L} / \mathrm{m}$ sebesar $2613.33 \mathrm{mg} / \mathrm{l}$. Pada hari kelima konsentrasi COD paling tinggi 
kembali terjadi pada reaktor kontrol sebesar $9713.33 \mathrm{mg} / \mathrm{l}$ dan konsentrasi paling rendah pada reaktor $6 \mathrm{~L} / \mathrm{m}$ sebesar $3473.33 \mathrm{mg} / \mathrm{l}$. Pada hari keenam konsentrasi COD paling tinggi masih terjadi pada reaktor kontrol sebesar $17866.67 \mathrm{mg} / \mathrm{l}$ dan konsentrasi paling rendah pada reaktor $2 \mathrm{~L} / \mathrm{m}$ sebesar 6780.00 $\mathrm{mg} / \mathrm{l}$. Pada hari ketujuh konsentrasi COD paling tinggi juga terjadi pada reaktor kontrol sebesar $10626.67 \mathrm{mg} / \mathrm{l}$ dan konsentrasi paling

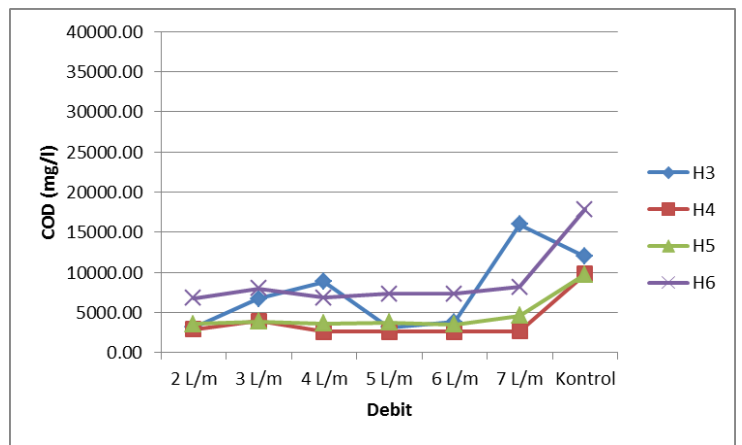

(a) rendah pada reaktor $4 \mathrm{~L} / \mathrm{m}$ sebesar 5313.33 $\mathrm{mg} / \mathrm{l}$. Pada hari kesembilan konsentrasi COD paling tinggi terjadi pada reaktor $5 \mathrm{~L} / \mathrm{m}$ sebesar $9826.67 \mathrm{mg} / \mathrm{l}$ dan konsentrasi paling rendah pada reaktor $7 \mathrm{~L} / \mathrm{m}$ sebesar $7626.67 \mathrm{mg} / \mathrm{l}$. Dan pada hari kesebelas konsentrasi COD paling tinggi terjadi pada reaktor $3 \mathrm{~L} / \mathrm{m}$ sebesar $37653.33 \mathrm{mg} / \mathrm{l}$ sedangkan konsentrasi paling rendah pada reaktor $2 \mathrm{~L} / \mathrm{m}$ dan $4 \mathrm{~L} / \mathrm{m}$ sebesar $13360.00 \mathrm{mg} / \mathrm{l}$.

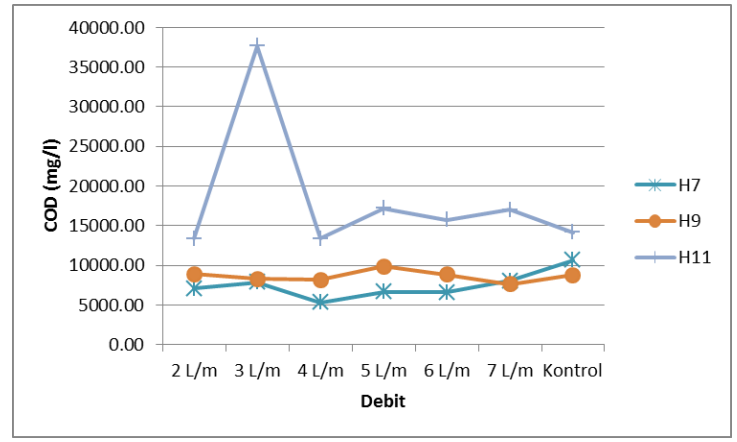

(b)

Gambar 4. Grafik Pengaruh Debit Aerasi terhadap Konsentrasi COD Lindi H3-H6 (a) dan Pengaruh Debit Aerasi terhadap Konsentrasi COD Lindi H7-H11 (b)

Berdasarkan data pengamatan dan grafik di atas dapat dilihat bahwa pemberian aerasi memberikan pengaruh sangat signifikan terhadap pengurangan konsentrasi COD lindi yang dihasilkan dari proses pengolahan sampah secara biodrying. Reaktor kontrol tanpa aerasi memiliki tingkat konsentrasi COD paling tinggi dari semua reaktor hampir di semua hari. Menurut Erses dkk, (2008) aerasi memungkinkan biodegradasi materi organic lebih cepat dan signifikan. Hidrolisis organic kompleks dengan kehadiran oksigen menaikan laju degradasi dan mengkonversinya menjadi karbon organic unruk selanjutnya dikonversi menjadi sebagian besar karbon dioksida dan air.

Hal yang sama dinyatakan oleh Ritzkowski dkk, (2006) karena metabolisme aerobik secara signifikan lebih cepat daripada metabolisme anaerobik, aerasi pada sampah menyebabkan reduksi konsentrasi organic lindi dengan cepat. Pada saat kondisi aerobik pula mikroba mampu mendegradasi organic semibiodegradable dan susah terdegradasi seperti selulosa dan lignin dimana keduanya memiliki resistan yang tinggi pada proses degradasi anaerobik.

Berdasarkan data hasil pengamatan dan analisis menunjukan aerasi memberikan efek yang signifikan terhadap reduksi konsentrasi COD lindi. Hal ini sesuai dengan yang dinyatakan oleh Erses dkk, (2008) bahwa reaktor aerobik lebih efektif dalam penyisihan COD dan stabilisasi sampah.

\section{KESIMPULAN}

Teknologi pengolahan limbah padat menggunakan proses Biodrying (Biological drying) merupakan salah satu alternatif biokonversi mekanikal-biologikal untuk mengolah sampah. Kesimpulan penelitian ini adalah:

a. Penambahan aerasi pada proses biodrying hanya menghasilkan lindi sebesar 1.279,5 $\mathrm{ml}$ dengan debit 3 liter/menit sedangkan tanpa aerasi menghasilakn lindi lebih banyak sebesar 1.607,5 ml.

b. Suhu sampah mengalami fluktuasi pada semua reaktor. Secara umum suhu tertinggi pada hari kedua dan ketiga. Pada hari keenam semua reaktor menunjukkan grafik kenaikan dan penurunan suhu sampah yang realtif seragam.

c. Nilai pH berkisaran antara 6,09-8,88 dan nlai COD akhir pada reaktor kontrol tanpa aerasi sebesar 14.116,67 mg/l sedangkan COD paling rendah sebesar $13.360 \mathrm{mg} / \mathrm{l}$ yang dihasilkan dari reaktor dengan debit $2 \mathrm{l} / \mathrm{m}$.

\section{SARAN}

Penelitian biodrying masih menghasilkan lindi dengan kadar COD tergolong tinggi. Namun disisi lain mampu mengurangi vulume total lindi yang dihasilkan. Target pencapaian zero lechate belum tercapai. 
Adani F, Baido D, Calcaterra E, Genevini P L, 2002. The influence of biomass temperature on biostabilization-biodrying of municipal solid waste. Bioresour Technol, 83(3): 173-179.

Bezama A, Aguayo P, Konrad O, Navia R, Lorber K E, 2007. Investigations on mechanical biological treatment of waste in South America: Towards more sustainable MSW management strategies. Waste Manage, 27(2): 228237

He, P J, Shao L M, Qu X, Li G J, Lee D J, 2005. Effects of feed solutions on refuse hydrolysis and land $\mathrm{fi}$ II leachate characteristics. Chemosphere, 59(6): 837-844

Nguyen, P. H. L., Kuruparan P, Visanathan C, 2007. Anaerobic digestion of municipal solid waste as a treatment prior to landfill. Bioresour Technol, 98(2): 380-387.

Semakot. "Semarang Akan Jadi Kota Bersih Sampah". $26 \quad$ Februari 2016. https://hariansemarang.com/berita/2016/0 2/22/semarang-akan-jadi-kota-bersihsampah/

Sugni $M$, Calcaterra $E$, Adani $F$, 2005.Biostabilization-biodrying of municipal solid waste by inverting air-flow. Bioresour Technol, 96(12): 1331-1337

Velis, C.A., P.J. Longhurst, G.H. Drew, R. Smith, S.J.T. Pollard. 2009. Biodrying for mechanical-biological treatment of wastes: A review of process science and engineering. UK: Bioresource Technology 100 (2009) 2747-2761 